\title{
Classroom Teachers' Attitudes to Nutrition Education and the School Food Environment: An Online Survey in Turkey
}

\author{
Nazan Aktas (Corresponding author) \\ Department of Nutrition and Dietetic, Faculty of Health Sciences, \\ Selçuk University, Konya, Turkey \\ E-mail of the naktas@ selcuk.edu.tr \\ Isobel R. Contento \\ Mary Swartz Rose Professor of Nutrition and Education, Program in Nutrition, \\ Department of Health and Behavior Studies Teachers College, \\ Columbia University, New York, NY 10027, USA \\ Osman Guldemir \\ Department of Cookery, Vocational School of Eskisehir, \\ Anadolu University, Eskisehir, 26470, Turkey \\ Pamela A. Koch \\ Program in Nutrition, Department of Health and Behavior Studies Teachers College, \\ Columbia University, New York, NY 10027, USA
}

\begin{abstract}
The objective of this study to determine the attitudes of elementary school teachers in Turkey towards nutrition education, nutrition courses in schools and the school food environment and to analyze differences by gender. The study used a cross-sectional online survey design. Descriptive statistics were used for the demographic characteristics and teachers' attitudes. Teachers' attitudes by gender were analyzed using independent $t$ tests. Participants were 1796 elementary classroom teachers in 527 schools, $56 \%$ male. Teachers rated highly that classroom nutrition education is very important (mean $=4.17$ on a 5-point scale), and should be practical (3.66); that nutrition taught as a separate subject was more likely to be effective (3.99) and government agencies, universities, and teachers should collaborate to provide it (4.34). They agreed that the school food environment can have a positive influence on student nutrition habits (4.32). Women teachers judged all attitude statements more positively than men, many significantly so. Classroom teachers have very positive attitudes towards practical nutrition education in the classroom and improving the school food environment. Providing teachers with the necessary culturally-based curricula and skills and having them collaborate with relevant agencies and organizations may contribute to their effectiveness.
\end{abstract}

Keywords: teacher attitudes, nutrition education, nutrition courses, school food environment, food service

DOI: $10.7176 / \mathrm{JHMN} / 75-10$

\section{Introduction}

Turkey is in transition to a more developmentally advanced economy and is beginning to experience the double burden of both increasing rates of obesity on the one hand and under nutrition and micronutrient deficiencies on the other hand (Popkin 2009). Such a nutrition transition is occurring in other parts of the Middle East, so Turkey could potentially become a model for nutrition education for the region. Nutrition education is increasingly important because the food environment is changing in both homes and awayfrom-home settings such as restaurants that may contribute to youth developing poor eating habits (Köksal 2006). Since healthful eating patterns may contribute to children's readiness to learn, schools can provide an excellent setting for positively influencing children's eating patterns, and as well as provide students with needed education and skills for their future lives (Kandiah \& Jones 2002; Worsley 2005; Hayes et al. 2018). School aged period is an important time for nutrition education as schools and

71 I P a g e

www.iiste.org 
teachers may begin to have more impact on a child's health habits during these years (Worsley 2005). Identification of students' as well as teachers' attitudes towards and perceptions of food and nutrition, including motivation, is an important element in the early stages of programme development (PerezRodrigo \& Aranceta 2001). Teachers has good knowledge about nutritional reflect on child's growth and health status. School meals are not provided by government; most students bring their lunches from home. The studies carried out so far in Turkey have examined the nutrition knowledge and personal eating habits of classroom teachers (Sabbağ et al. 2006; Çakıroğlu et al. 2007; Memiş \& Şanlıer 2010). In Turkey, nutrition education in primary education tends to be taught life sciences, social studies, and science classes.

There has been some concern that nutrition education has not been properly taught through these subject areas. However, there is no study with a large sample investigating teachers' attitudes towards nutrition education in general, how it should be taught in schools, and the school food environment. Yet it is important to identify the perspectives of teachers as they are significant partners in school-based nutrition education and can contribute to improving the health of children. The purpose of this study was to describe the attitudes of a sample of classroom teachers in Turkey towards nutrition education, nutrition courses in school, and the food environment including food service, using a web-based survey.

\section{Material and Methods}

This study used a survey design involving a web-based questionnaire to describe the attitudes of teachers. The data were collected online via the e-school system. e-school is an electronic environment for official educational transactions that only teachers and administrators can access with individual user names and passwords. The Web master of e-school is the Turkish Ministry of Education. Web-based questionnaires have several advantages compared to paper questionnaires including improved data quality, and reduction of costs by as much as a third, reduction in the burden for respondents and time from initiation of the study to the receipt of analyzable data (Mangunkusumo et al. 2005; Majd 2006; Ekman et al. 2006).

This research was done in Konya, Turkey's seventh largest city, with a population of about 2 million and located in Central Anatolia in the middle of the country, and typical of many other mid-sized cities in the country. The survey was sent to a random half of all teachers by the Research \& Development Department of the Konya Provincial Directorate for National Education, resulting in 7244 classroom teachers in 934 elementary schools. The survey was completed by 1796 teachers in 527 schools for response rates of 24.5\% and 56.4\% respectively (Tipton 2013). Participation was voluntary and teachers were not compensated for participating. The instrument was developed specifically for this study. It was designed to determine the demographic characteristics of teachers and to answer the questions: What are teachers' attitudes towards nutrition education? What are their attitudes to nutrition education in the classroom? What do they think about the school food environment? The instrument contained information on the aims of the study and instructions on how to complete it. It was first pilot-tested with 83 primary school teachers, resulting in recommendations for several changes in wording for clarity. These teachers were omitted from the roster of teachers before the final sample was selected to receive the questionnaire. Response options were based on a 5 -point Likert scale $(1=$ strongly disagree to $5=$ strongly agree). Factor analysis was conducted on the questionnaire with varimax rotation, which yielded three distinct factors or scales that accounted for $46.9 \%$ of the variance. These factors were labeled as "classroom teachers' attitudes towards the importance of nutrition education in schools;" "classroom teachers' attitudes towards nutrition education in the classroom," and "classroom teachers' attitudes towards the school environment and food services." The scales showed good internal consistency reliabilities, with Cronbach alpha coefficients of $0.730,0.680$, and 0.638 respectively.

The research protocol and instrument were approved by the members of the Commission at Konya Provincial National Education Directorate (Institutional Review Board). Instructions stated that by completing the survey, teachers were giving their active consent for the study. The instrument was then transferred to the $e$-school system by the relevant unit. Participants completed the instrument only once with their individual user name and password. The system did not allow the same user name and password to fill out the survey again.

The data obtained through the electronic instrument were analyzed using Statistical Package for the Social Sciences (version 17). There were missing data for 48 teachers, who were removed from the sample. We analyzed the demographic data using descriptive statistics with means and standard deviations. For teachers' attitudes towards the importance of nutrition education, nutrition education in classroom, and the school food environment, we calculated the mean for each of the questions and for

72 | P a g e

www.iiste.org 
the scales. We also analyzed teachers' attitudes by gender using the independent $t$ test. The level of significance for all statistical tests was set at $\mathrm{P}<.05$.

\section{Results}

About $82 \%$ of the classroom teachers had completed undergraduate degrees and $6.8 \%$ master's degrees or the Ph.D. About 10\% had completed teacher education at the high school level, an option that no longer exists. About 56\% were males and 44\% females. Almost half of participants (48.7\%) were between 31-40 years old; $28.7 \%$ were $20-30$, and $19.9 \%$ were $41-50$.

Table 1 shows that teachers gave a mean rating of 4.32 on a 1-5 point scale for the importance of nutrition education in schools. The highest ratings were given to the attitude statements that healthy nutrition affects the achievement level of students, and that nutrition education is important and should not be neglected in primary schools. The lowest rating was given to the statement nutrition knowledge is more important than economic status for healthy eating.

Table 1. The classroom teachers' attitudes towards the importance of nutrition in schools

\begin{tabular}{|c|c|c|c|c|c|}
\hline Attitudes & $\begin{array}{l}\text { Total } \\
\text { Mean }\end{array}$ & $\begin{array}{l}\text { Male } \\
\mathbf{n}=1001 \\
\bar{\chi} \\
\left(S_{X}\right)\end{array}$ & $\begin{array}{c}\begin{array}{c}\text { Female } \\
\mathbf{n}=795 \\
\bar{\chi} \\
\left(s_{X}\right)\end{array} \\
\end{array}$ & $\begin{array}{c}t \\
\text { statistics }\end{array}$ & $\begin{array}{c}\text { p- } \\
\text { value }\end{array}$ \\
\hline $\begin{array}{l}\text { Nutrition education should be given place in } \\
\text { all stages of elementary school education }\end{array}$ & $\begin{array}{c}4.17 \\
(1.02)\end{array}$ & $\begin{array}{c}4.12 \\
(1.03)\end{array}$ & $\begin{array}{l}4.24 \\
(.99)\end{array}$ & -2.483 & .013 \\
\hline $\begin{array}{l}\text { Nutrition knowledge is more important than } \\
\text { economic status for healthy eating }\end{array}$ & $\begin{array}{c}3.74 \\
(1.22)\end{array}$ & $\begin{array}{c}3.76 \\
(1.21)\end{array}$ & $\begin{array}{c}3.72 \\
(1.24)\end{array}$ & .690 & .490 \\
\hline $\begin{array}{l}\text { Healthy nutrition affects the achievement } \\
\text { level of students }\end{array}$ & $\begin{array}{l}4.69 \\
(.67)\end{array}$ & $\begin{array}{c}4.65 \\
(1.21)\end{array}$ & $\begin{array}{l}4.74 \\
(.58)\end{array}$ & 2.807 & .005 \\
\hline $\begin{array}{l}\text { Students should learn about food label } \\
\text { reading in schools }\end{array}$ & $\begin{array}{l}4.39 \\
(.77)\end{array}$ & $\begin{array}{l}4.34 \\
(.79)\end{array}$ & $\begin{array}{l}4.45 \\
(.73)\end{array}$ & 3.051 & .002 \\
\hline $\begin{array}{l}\text { Ministries of Health, National Education, } \\
\text { Agriculture-Rural Affairs and universities } \\
\text { have to cooperate in providing nutrition } \\
\text { education in primary schools }\end{array}$ & $\begin{array}{l}4.34 \\
(.82)\end{array}$ & $\begin{array}{l}4.32 \\
(.87)\end{array}$ & $\begin{array}{l}4.36 \\
(.76)\end{array}$ & .993 & .321 \\
\hline $\begin{array}{l}\text { Nutrition education is important and should } \\
\text { not be neglected in primary school education } \\
\text { for the health and nutritional well-being of } \\
\text { children }\end{array}$ & $\begin{array}{l}4.58 \\
(.73)\end{array}$ & $\begin{array}{l}4.54 \\
(.77)\end{array}$ & $\begin{array}{l}4.62 \\
(.67)\end{array}$ & -2.329 & .020 \\
\hline Total Mean & & $\begin{array}{l}4.29 \\
(.61)\end{array}$ & $\begin{array}{l}4.35 \\
(.19)\end{array}$ & 2.414 & .005 \\
\hline
\end{tabular}

From table 2 we see that teachers gave a mean rating of 3.51 for attitudes towards teaching nutrition in the classroom. The highest score was for nutrition to be taught as an independent subject. Teachers agreed that teaching nutrition in different subject areas was not adequate for children to form healthy nutrition habits and that there were not enough practical applications when nutrition was taught as part of other subject areas. The lowest score was given to teaching basic cooking and food preparation skills. Teachers' attitudes toward the school food environment varied from a high rating of 4.57 for schools should provide fruit, fruit juice, and milk in the cafeteria, to a low of 3.32 that kitchens should be available on school premises for students and teachers to use. They agreed that the school environment can have a positive effect on children's dietary habits and that standardized tests can impact dietary habits of children (Table $3)$. 
Table 2. The classroom teachers' attitudes towards nutrition in the classroom

\begin{tabular}{|c|c|c|c|c|c|}
\hline Attitudes & $\begin{array}{l}\text { Total } \\
\text { Mean }\end{array}$ & $\begin{array}{l}\text { Male } \\
\mathbf{n = 1 0 0 1} \\
\bar{\chi} \\
\left(s_{x}\right)\end{array}$ & $\begin{array}{c}\text { Female } \\
\mathbf{n}=795 \\
\bar{\chi} \\
\left(s_{x}\right)\end{array}$ & $\stackrel{t}{t}$ & $\begin{array}{c}\text { p- } \\
\text { value }\end{array}$ \\
\hline $\begin{array}{l}\text { Nutrition taught as an independent } \\
\text { nutrition subject can play an } \\
\text { important role for students to gain } \\
\text { healthy nutrition behaviors. }\end{array}$ & $\begin{array}{c}3.99 \\
(1.12)\end{array}$ & $\begin{array}{c}3.90 \\
(1.17)\end{array}$ & $\begin{array}{c}4.10 \\
(1.03)\end{array}$ & -3.842 & .000 \\
\hline $\begin{array}{l}\text { Nutrition taught in different subject } \\
\text { areas is not adequate to form healthy } \\
\text { nutrition habits. }\end{array}$ & $\begin{array}{c}3.51 \\
(1.12)\end{array}$ & $\begin{array}{c}3.43 \\
(1.15)\end{array}$ & $\begin{array}{c}3.61 \\
(1.06)\end{array}$ & -3.540 & .000 \\
\hline $\begin{array}{l}\text { It is difficult to instill healthy } \\
\text { nutrition behaviors because there are } \\
\text { not enough practical applications } \\
\text { about food in taught in various } \\
\text { subject areas. }\end{array}$ & $\begin{array}{c}3.66 \\
(1.06)\end{array}$ & $\begin{array}{c}3.58 \\
(1.11)\end{array}$ & $\begin{array}{l}3.76 \\
(.98)\end{array}$ & -3.613 & .000 \\
\hline $\begin{array}{l}\text { Basic cooking and food preparation } \\
\text { skills should be gained by students in } \\
\text { the classroom }\end{array}$ & $\begin{array}{c}2.89 \\
(1.24)\end{array}$ & $\begin{array}{c}2.85 \\
(1.26)\end{array}$ & $\begin{array}{c}2.93 \\
(1.22)\end{array}$ & -1.254 & .210 \\
\hline Total Mean & & $\begin{array}{l}3.44 \\
(.26)\end{array}$ & $\begin{array}{l}3.60 \\
(.26)\end{array}$ & 4.209 & .002 \\
\hline
\end{tabular}

Table 3. The classroom teachers' attitudes school environment \& food services

\begin{tabular}{|l|c|c|c|c|c|}
\hline \multicolumn{1}{|c|}{ Attitudes } & $\begin{array}{c}\text { Total } \\
\text { Mean }\end{array}$ & $\begin{array}{c}\text { Male } \\
\mathbf{n = 1 0 0 1} \\
\bar{\chi} \\
\left(s_{X}\right)\end{array}$ & $\begin{array}{c}\text { Female } \\
\mathbf{n = 7 9 5} \\
\bar{\chi} \\
\left(s_{X}\right)\end{array}$ & $\begin{array}{c}\mathbf{t} \\
\text { statistics }\end{array}$ & $\begin{array}{c}\text { p- } \\
\text { value }\end{array}$ \\
\hline $\begin{array}{l}\text { There should be fresh fruits, fruit juice and } \\
\text { milk in the school canteen }\end{array}$ & $\begin{array}{c}4.57 \\
(.88)\end{array}$ & $\begin{array}{c}4.52 \\
(.94)\end{array}$ & $\begin{array}{c}4.63 \\
(.80)\end{array}$ & -2.666 & .008 \\
\hline $\begin{array}{l}\text { Interaction between nutrition and health } \\
\text { should be learned at school and through the } \\
\text { school environment }\end{array}$ & $\begin{array}{c}3.93 \\
(1.15)\end{array}$ & $\begin{array}{c}3.92 \\
(1.13)\end{array}$ & $\begin{array}{c}3.94 \\
(1.17)\end{array}$ & -.426 & .670 \\
\hline $\begin{array}{l}\text { There should be kitchens for students and } \\
\text { for teachers on school premises }\end{array}$ & $\begin{array}{c}3.32 \\
(1.29)\end{array}$ & $\begin{array}{c}3.27 \\
(1.29)\end{array}$ & $\begin{array}{c}3.38 \\
(1.28)\end{array}$ & -1.725 & .085 \\
\hline $\begin{array}{l}\text { Nutrition clubs have a unique place among } \\
\text { educational clubs }\end{array}$ & $\begin{array}{c}3.71 \\
(1.12)\end{array}$ & $\begin{array}{c}3.61 \\
(1.17)\end{array}$ & $\begin{array}{c}3.83 \\
(1.05)\end{array}$ & -4.108 & .000 \\
\hline $\begin{array}{l}\text { School and school environment have } \\
\text { positive effects on nutrition habits. }\end{array}$ & $\begin{array}{l}4.32 \\
(.80)\end{array}$ & $\begin{array}{c}4.29 \\
(.82)\end{array}$ & $\begin{array}{c}4.36 \\
(.77)\end{array}$ & -1.848 & .065 \\
\hline $\begin{array}{l}\text { Placement Test (PT) and Secondary } \\
\text { Education Test (SET) affect the nutritional } \\
\text { habits of students }\end{array}$ & $\begin{array}{c}3.94 \\
(1.08)\end{array}$ & $\begin{array}{c}3.84 \\
(1.14)\end{array}$ & $\begin{array}{l}4.07 \\
(.99)\end{array}$ & -4.568 & .000 \\
\hline Total Mean & $\begin{array}{c}3.91 \\
(.66)\end{array}$ & $\begin{array}{c}4.03 \\
(.60)\end{array}$ & 4.223 & .007 \\
\hline Cronbach's Alpha: 0.638; nof items: 6 & & & & \\
\hline
\end{tabular}

When we compared the data for women and men classroom teachers, women teachers had significantly higher mean scores on all three of the scales in the instrument than male teachers $(p<.005$ to $p<0001)$ (Tables 1-3). More specifically, in terms of attitudes towards the importance of nutrition education (Table 
1), women teachers were significantly more likely than men to rate nutrition education as important, should be given place in elementary education, and should include applications such as food label reading. Table 2 shows that women teachers were significantly more likely than men to agree that it is difficult to instill healthy behaviors in schools because there were not enough practical applications being taught; that nutrition taught as a separate subject was more likely to contribute to healthy nutrition behaviors, while teaching it in different subject areas was less like to do so. In Table 3, women were significantly more likely to agree that fresh fruit, fruit juice and milk should be available in the school cafeteria and that standardized tests affect student's diets.

\section{Discussion}

The purpose of this study was to describe the attitudes of teachers toward nutrition education in general, how it is taught in the classroom, and the school food environment. In particular is sought to fill a gap: a prior study in Turkey had concluded that nutrition as taught in primary education did not seem to be appropriate and needed to be re-designed (Çakıroğlu et al. 2007). The results of this survey provided some information relevant to this concern.

From the results, it is clear that the teachers had very positive attitudes towards nutrition education and believed that it should be provided at all stages of elementary education. But they believed that it should include practical applications to life. They noted that instilling healthy behaviors was currently difficult because such applications were absent in schools. This is very encouraging. Such a practical approach is especially necessary at this time to bring about healthy eating patterns in children because Turkey is undergoing a nutrition transition to a more obesogenic and less healthful food supply as part of its economic transition. Indeed, teachers believed to some extent that knowledge had become more important than economic status for healthy eating. Teachers believed that nutrition taught as a separate subject was more likely to be effective in changing behaviors than when it was integrated into other subject areas; in Turkey, these were most commonly biology, social studies, and science. In these subject areas, nutrition education tended to be about nutrition facts. The debate about teaching nutrition as a separate subject or integrated to other subjects has taken place in many countries (Contento et al. 1995). Teachers are under pressure to teach towards educational standards in Turkey as in other countries, in this case the Placement Test, Secondary Education Test or High School Entrance Examination which could pressure on the education system too (TEDMEM 2019). Hence there is pressure for nutrition education to serve other educational goals as well. Yet nutrition education is more likely to be effective when it is behaviorally focused, increases motivation, and facilitates behavior change by providing opportunities to learn goal setting and practice the food and nutrition-related skills to achieve them (Contento et al. 1995; Hayes et al. 2018). In the United States, most nutrition education curricula are designed to address various educational standards at the same time - such as math, reading, science, or social science (Shilts et al. 2009). However, achieving both behavioral change goals and other educational goals at the same time requires coordination and skills on the part of teachers. In addition, a study in Turkey found that about $70 \%$ of elementary school teachers were not sufficiently knowledgeable about nutrition (Sabbağ et al. 2006). Thus, they need a good curriculum and strong professional development (Contento et al. 1995; Hayes et al. 2018).

Interestingly, teachers highly endorsed the idea of teaching the practical skill of reading food labels, but not cooking and food preparation skills. Label reading is presumably considered important because more processed, packaged foods are becoming available. Cooking activities in schools have gained popularity in American and European schools, being seen as motivating to children and because such skills are considered important for healthy eating (Liquori et al. 1998; Lukas \& Cunningham-Sabo 2011). A few studies have shown that cooking as part of classroom nutrition education can result in healthier food choices in schools, leading the authors to state that actual cooking experiences and eating food with peers, accompanied by cognitive learning, may provide a promising approach to nutrition education (Liquori et al. 1998; Lukas \& Cunningham-Sabo 2011; Carather et al. 2013).

The fact that Turkish teachers did not consider cooking to be important by may be because such skills are considered to belong in home economics classes and not in the standard elementary school curriculum or that cooking is routinely still learned at home. Thus, teachers can be made aware of the usefulness of cooking in nutrition education in regular classrooms as a means to enhance motivation and healthy eating and that the knowledge and skills gained can address national educational standards for a variety of subjects at the same time.

The teachers in this survey recognize the importance of the food environment, in and outside of school, believing that it affects student's eating habits. Most students bring their lunches to school in Turkey,

75 | P a g e

www.iiste.org 
hence the question about availability of school kitchens for use by students and teachers were included; this would permit them to do minor food preparation. The mean score for this question suggests that teachers were neutral about this issue. The teachers strongly believed that the school cafeterias should make fruit, fruit juice, and milk available. These beliefs echo those in Europe and the US that to improve children's diets and reduce obesity risk healthy school food environments and practices are essential (Briefel 2009). A number of studies conducted in school settings have examined interventions to increase fruit and vegetable consumption in multiple ways: offering free fresh fruits and vegetables, providing variety through salad bars, improving the quality and variety of fresh fruits and vegetables offered in school meals, providing nutrition education to children and families, and making food service changes (Neumark-Sztainer et al. 2003; Wojcicki \& Heyman 2006; Slusser et al. 2007; Diab 2015). Some of these strategies may be suitable for Turkey. The teachers rated very highly the importance of inter-institutional cooperation in nutrition education, involving the ministries of health, national education, agriculturerural affairs, and universities. Such collaboration has been advocated in other countries as well (WHO 2007). The ministry of health in Turkey has many published and online resources that would be very useful to teachers. Professional development sessions for teachers could make teachers aware of these resources. New resources could be developed specifically for Turkish teachers. In addition, the country needs to develop interesting and engaging, culturally appropriate, practice focused, theoretically grounded nutrition education curricula and materials that appeal strongly to children. The ministry of education could partner with universities that would provide expertise in developing and evaluating appropriate curricula for the schools. Universities could also provide in-service sessions about the social ecological model and to get the various ministries to participate. The ministry of education could include competencies in nutrition as part of the required elementary school curriculum. Such collaborations would strengthen nutrition education in the schools.

Almost half the teachers in Turkish primary schools are men, a figure much higher than in those in developed countries. This statistic reflects the social structure that favors male employment. Women teachers scored higher than men on all attitude statements, with many significantly so. However, the actual differences are minor in practical terms, suggesting that professional development can address all teachers similarly.

The study was based on a large number of teachers from a city in the middle of the country that is similar to many others in Turkey. The response rate was almost equal for male and female teachers, representing approximately the gender composition of all teachers in the country. The survey asked questions of importance for decision-making about nutrition education. The study also has some limitations. The response rate of teachers of about $25 \%$ is low. However, the response rate of schools represented by these teachers was about $56 \%$. It is considered that the response rate of schools is more important for generalizability (WHO 2007). The fact that slightly more than half the schools were represented in the survey is thus encouraging. Nevertheless, interpretations of results need to be made with caution.

\section{Conclusion}

This study found that classroom teachers have positive attitudes towards various aspects of the importance of school-based nutrition education (lectures, program, inter-institutional collaboration, practices, kitchen practices, exams, school environment, food services, etc). In regards to the importance of nutrition education, both female and male teachers had the most positive score for the question healthy nutrition affects the achievement level of students. This shows an intrinsic motivation for nutrition education because of perceived benefits for both students, to have high achievement, and teachers, who want students to have high achievement and are often evaluated on student achievement. Additionally, teachers felt strongly that nutrition education should be an independent subject and plays a role for students to gain healthy nutrition behaviors. Given these positive attitudes future studies can investigate what types of professional development build confidence in teachers to provide behaviorally-focused nutrition education. Additionally, more research should be devoted to developing and evaluating the effectiveness of curricula that are practice-focused, theory-based, and culturally appropriate that could be adapted for other countries in the region based on local formative assessments. Finally, the processes used to foster collaboration among agencies and universities could be carefully documented and evaluated. Effective strategies could inform other countries in the region for how to best support nutrition education at the national level. 


\section{References}

Briefel, R.R., Crepinsek, M.K., Cabilli, C.C., Wilson, A. \& Gleason, P.M. (2009), "School food environments and practices affect dietary behaviors of US public school children", Journal of the American Dietetic Association 109, 91-107.

Çakıroğlu, F.P., Uçar, A. \& Kuş, S. (2007), "The point of view of primary school teachers on nutrition education", The Teacher and the Teaching Profession: Current Research and International Issues (Edited by M.S. Giannakaki), Greece: Athens Institute for Education and Research, 77-90.

Carather, M., Seeley, A., Wu, M. \& Lloyd, S. (2013), "When chefs adopt a school? An evaluation of a cooking intervention in English primary schools", Appetite 62, 50-59.

Contento, I., Balch, G.I., Bronner, Y.L., Lylt, L.A., Maloney, S.K., Olson, C.M. \& Swaneder, S.S. (1995), "The effectiveness of nutrition education and implications for nutrition education policy programs and research: A review of research", Journal of Nutrition Education 27, 277-422.

Diab, S. (2015), "Effect of Nutritional Guideline for Kindergarten Teachers on Healthy Physical Growth of Preschool Children", IOSR Journal of Research \& Method in Education 5(4), 17 25.

Ekman, A., Dickman, P.W, Klint, A., Weiderpass, E. \& Litton, J.E. (2006), "Feasibility of using webbased questionnaires in large population-based epidemiological studies", European Journal of Epidemiology 21, 103-111.

Hayes, D., Contento, I. R., \& Weekly, C. (2018). "Position of the Academy of Nutrition and Dietetics, Society for Nutrition Education and Behavior, and School Nutrition Association: comprehensive nutrition programs and services in schools". Journal of the Academy of Nutrition and Dietetics 50(5): 433-439.

Kandiah, J. \& Jones, C. (2002), "Nutrition knowledge and food choices of elementary school children", Early Child Development and Care 172, 269-273.

Köksal, E. (2006), "Nutrition and health status of school children in Turkey and approaches", $V$. International Nutrition and Dietetics Congress, ISBN: 975-491-211-4.

Liquori, T., Koch, P. D., Contento, I.R. \& Castle, J. (1998), “The Cookshop program: outcome evaluation of a nutrition education program linking lunchroom food experiences with classroom cooking experiences", Journal of Nutrition Education 30, 302-313.

Lukas, C.V. \& Cunningham-Sabo, L. (2011), "Qualitative investigation of the Cooking with Kids program: focus group interviews with fourth-grade students, teachers, and food educators", Journal of Nutrition Education 43, 517-524.

Majd, T.M. (2006), “Invest in Yourself”, Nursing Forum 41, 41-45.

Mangunkusumo, R.T., Moorman, P.W., Ruiter, V.D.B.A., Lei, J.V.D., Koning, H.J.D. \& Raat, H. (2005), "Internet-administered adolescent health scales compared with a paper version in a randomized study", Journal of Adolescent Health 36, 70.e1-70e6.

Memiş. E. \& Şanlıer, N. (2010), “Analysis of nutrition habits of the teachers and nurses”, Pakistan Journal of Nutrition 9, 1176-1182.

Neumark-Sztainer, D., Wall, M., Peery, C. \& Story, M. (2003), “Correlates of fruit and vegetables intake among adolescents. Findings from Project EAT”, Preventive Medicine 37, 198-208. 
Perez-Rodrigo, C. \& Aranceta, J. (2001), "School-based nutrition education: lessons learned and new perspectives", Public Health Nutr 4(1A), 131-39.

Popkin, B.M. (2009), "Global nutrition dynamics: the world is shifting rapidly toward a diet linked with non-communicable diseases”, American Journal of Clinical Nutrition 84, 289-298.

Sabbağ, Ç., Sürücüoğlu, M.S., Özçelik, A.Ö. \& Akan, L.S. (2006), “A Research on nutrition knowledge of elementary school teachers: a sample of Turkey", Research on Education (Edited by M.S. Giannakaki, G.T. Papanikos, Y. Pozios \& J.K. Richards). Greece: Athens Institute for Education and Research, 441-452.

Shilts, M.K., Lamp, C., Horowizt, M. \& Townsend, M. (2009), "Pilot Study: Eat Fit impacts sixth graders' academic performance on achievement of mathematics and English education standards", Journal of Nutrition Education and Behavior 41, 127-131.

Slusser, W.M., Cumberland, W.G., Browdy, B.L., Lange, L. \& Neumann, C. (2007), “A school salad bar increases frequency of fruit and vegetables consumption among children living in low-income households", Public Health Nutrition 10, 1490-1496.

TEDMEM. (2019). 2018 eğitim değerlendirme raporu (TEDMEM Değerlendirme Dizisi 5). Ankara: Türk Eğitim Derneği.

Tipton, E. (2013), "Stratified sampling using cluster analysis: A balanced-sampling strategy for improved generalizations from experiments", Evaluation Review 37(2), 109-139.

WHO (World Health Organization). (2007), The world health report 2007: a safer future: global public health security in the 21st century, ISBN 978924156344 4. Switzerland.

Wojcicki, J.M. \& Heyman M.B. (2006), "Healthier choices and increased participation in a middle school lunch program: effects of nutrition policy changes in San Francisco", American Journal of Public Health 96(9), 1542-1547.

Worsley, A. (2005), “Children's healthful eating: From research to practice”, The United Nations University, Food and Nutrition Bulletin 26(2), 135-143. 